\title{
Trauma, Memory and History in Kazuo Ishiguro's Fiction
}

\author{
Deyan Guo \\ College of Foreign Languages, Nankai University, China; \\ School of English Studies, Tianjin Foreign Studies University, China \\ Email: guodeyan@tjfsu.edu.cn
}

\begin{abstract}
Though Kazuo Ishiguro is not labelled as a writer of historical fiction, most of his writings until now are set against the backdrop of World War II, particularly the atomic bombing in Nagasaki, the postwar decline of British empire, and Japan's invasion to China. These historical scenarios provide Ishiguro with a context to explore the emotional and psychological trauma the war has inflicted on the protagonists, thus reminding the contemporary reader of the significance of remembering the past. His fiction also presents a picture of how individuals cope with their personal loss and how they go through the painful process from self-deception, to self-denial and last to self-redemption. And Ishiguro always ends his fiction with a hopeful note, giving the reader a sense of optimism toward the life ahead.
\end{abstract}

Index Terms - Kzauo Ishiguro, trauma, memory, history, World War II

\section{INTRODUCTION}

Among the six novels by now, Kazuo Ishiguro sets four of them around the Second World War except The Unconsoled (1995) which relates a pianist's dream-like experiences in an unnamed city of contemporary Central Europe and Never Let Me Go (2005) which poses an ethical question about the modern technique of cloning. As regards the historical context in his work, Ishiguro explains in an interview by François Gallix that in the initial stage of his writing, he simply joined the trend in contemporary British literature that historical fiction is a safe channel for British writers not to be labelled as being inward-looking and provincial. Quite a few writers who emerged in the 1980s are obsessed with the past "when everything was fragmented, when everything - democracy, stability - was really at risk" (Gallix, 2008, p.140), as Salman Rushdie, Graham Swift, Ian McEwan, Sebastian Faulks and Pat Barker do. A novel with reference to the holocaust or to the war can suddenly gain a kind of weight and claim somewhat significance. But that always made him uneasy, for he felt there was something wrong about such use of history. This kind of uneasiness was put at rest during his visit to Auschwitz camp in Poland in 1999. When he looked at the exhibition, the question suddenly sprang up in his mind: "How to keep the lessons of this rather awful century we've had when the people who have actually experienced it at first hand are now passing away" (p.141). At that moment he realized that his generation who grew up in the climate of the postwar era has the responsibility of keeping the memories of the past as a link between the older generation who lived through the war and the younger generation who even sees the cold war something so distant.

The past which Ishiguro frequently returns to is from the 1910s to the 1950s, especially the atomic bombing in Nagasaki, the decline of British empire after World War II, and Japan's invasion to China.

\section{ATOMIC BOMBING IN NAGASAKI}

Two atomic bombs ended the Second World War. At 8:15 A.M. on August 6, 1945, the B-29 Enola Gay, accompanied by two weather observation planes, invaded the skies of Hiroshima and dropped the first atomic bomb. Three days later, at 11:02 A.M. on August 9, the second atomic bomb was released from the B-29 over the city centre of Nagasaki. "The new type of bomb" compelled Emperor Hirohito to announce the unconditional surrender over the radio on August 15. Thus the Pacific War was over.

The damage to Hiroshima and Nagasaki was unimaginable. According to Eisei Ishikawa's (1981) description:

With the explosion of the atomic bomb, the epicenter instantaneously reached a maximum temperature of several million degrees centigrade and an atomspheric pressure of temperature of several 100,000 bars; with the formation of a fireball, powerful heat rays and radiation were emitted in all directions within a short interval. Radiation extended not only directly from the burst point but also from the surface of the ground - from fission fragments and the residue of neutron-induced radioactive materials. The shock waves propagated by the explosion and the tremendous blast that followed almost instantaneously demolished buildings and killed many people. The survivors suffered the agonies thermal burns and radiation exposure, whose effects were in many cases delayed. (p.22)

With houses being burned and flattened and thousands of people being killed (140,000 of Hiroshima's 350,000 inhabitants, and 70,000 of Nagasaki's 270,000 inhabitants lost their lives), the two cities were reduced into an earthly 
hell in an instant. Everything came so sudden that its impact on the survivors would materialize only in belated forms.

A Pale View of Hills (1982) and An Artist of the Floating World (1986) present a picture of the devastated Nagasaki. In A Pale View of Hills, the protagonist Etsuko who, together with her husband, lives in a newly erected apartment building to the east of Nagasaki, always watches through her window the open ground lying before her block:

A river ran near us, and I was once told that before the war a small village had grown up on the river bank. But then the bomb had fallen and afterwards all that remained were charred ruins. Rebuilding had got under way and in time four concrete buildings had been erected, each containing forty or so separate apartments. Of the four, our block had been built last and it marked the point where the rebuilding programme had come to a halt; between us and the river lay an expanse of wasteground, several acres of dried mud and ditches. Many complained it was a health hazard, and indeed the drainage was appalling. All year round there were craters filled with stagnant water, and in the summer months the mosquitoes became intolerable. (PAH, p.11)

Though it is around seven or eight years after the atomic bombing and the city is under the programme of reconstruction, the traces of the ruins are still to be found here and there. The expanse of wasteground, resembling T.S.Eliot's Waste Land and F. Scott Fitzgerald's Valley of the Ashes, reminds the inhabitants of what has occurred and metaphorically reflects the repressed lives of Etsuko, her friend Sachiko and Sachiko's daughter Mariko who take their temporary residence in the shabby wooden cottage, "standing alone at the end of that expanse of wasteground, practically on the edge of the river" (p.11).

The story of An Artist of the Floating World takes place during American Occupation of Japan (1945-1952), or to be more accurate from October, 1948 to June, 1950. The visual shocks of the devastation are more poignant than those in $A$ Pale View of Hills. Masuji Ono, the protagonist, has to spend his retirement days repairing his once grand house. Its long corridor, east wing and veranda have all received their shares of war damage. But the saddest sight of the damage is in the pleasure district of the city. Before the bombing, it has been such a prosperous and vigorous district that

On the warmer evenings particularly, the area would fill with people strolling unhurriedly from bar to bar, or just standing talking in the middle of the street. Cars had long ceased to venture through, and even a bicycle could only be pushed with difficulty past those throngs of uncaring pedestrians. (AFW, pp.23-4)

Yet now, only Mrs. Kawakami's bar stands there. Coming out of her bar, Ono feels like being placed in an "outpost of civilization" with nothing around but "a desert of demolished rubble" (p.26). Mrs. Kawakami describes it as a "graveyard." And the columns of smoke rising from the rubble, to Ono, look like "pyres at some abandoned funeral" (p.28).

These are the physical damages the bomb has incurred on Nagasaki and these damages can be gradually removed from people's memory when the new buildings are erected on the ruins. By contrast, the emotional and psychological traumas hold a more agonizing spell on the survivors. Since the bomb took almost one-quarter of Nagasaki's inhabitants, "citizens who had lost no family members in the holocaust were as rare as stars at sunrise" (Ishikawa, 1981, p.6). In $A$ Pale View of Hills, Mrs Fujiwara, Etsuko's former neighbor who led a comfortable life before the war, suffers a severe personal loss: The bomb took the lives of her husband and four children, leaving only her eldest son and herself alive. Even if she shows much courage to cope with the disaster, her busy schedule for everyday to run the small noodle shop somehow reveals that she strives to forget the grief by not giving herself any moment free for thinking about the dead. For once, she also admits to Etsuko that sometimes in the mornings, she wakes up unaware of where she is. Etsuko's loss is not less than Mrs. Fujiwara's. After the blast, she becomes an orphan and has to be taken into the home of Ogata-San, whose son Jiro later marries Estuko. When Etsuko first comes to stay with the Ogatas, she plays the violin in the dead of night like "a mad girl."

Another character who is more severely traumatized is the 10-year-old girl Mariko, Sachiko's daughter. The mother has her own share of grief in that she has to tolerate the arrogance of her cousin and the dull life at her uncle's house after the death of her husband. But she reorients her life towards immigrating to America, for her American boyfriend Frank promises to take her and Mariko away. The association with Frank makes her neglectful of the mentality of Mariko who always claims having seen a strange woman. The illusion of Mariko derives from her having witnessed a young mother drown her baby back in Tokyo when she was around five years old:

Mariko went running off one morning. I can't remember why, perhaps she was upset about something. Anyway she went running off out into the street, so I went chasing after her. It was very early, there was nobody about. Mariko ran down an alleyway, and I followed after her. There was a canal at the end and the woman was keeling there, up to her elbows in water. A young woman, very thin. I knew something was wrong as soon as I saw her. You see, Etsuko, she turned round and smiled at Mariko. I knew something was wrong and Mariko must have done too because she stopped running. At first I thought the woman was blind, she had that kind of look, her eyes didn't seem to actually see anything Well, she broughtf her arms out of the canal and showed us what she'd been holding under the water. It was a baby. I took hold of Mariko then and we came out of the alley. (PVH, p.74)

As far as Sachiko knows, that woman committed suicide a few days after her infanticide. Yet, Mariko repeatedly says that the woman has been following her from Tokyo to Nagasaki. Mariko's preoccupation with the imaginary woman confirms what the trauma theorist Cathy Caruth (1995) explains about the traumatized subject: "To be traumatized is precisely to be possessed by an image or event" (pp.4-5). Mariko's senses of fear and anxiety are complicated by Sachiko's frequent absence from home, leaving her alone or under the care of Etsuko. Feelings of insecurity and 
alienation arise, especially when she learns that her mother is determined to immigrate to America with Frank, the man she curses as "a pig." In this case, she projects her aspiration for a cozy and complete home onto the kittens she has nurtured. She looks after them as if they were her darling kids. However, this self-created world of warmth is destroyed by her mother before the day of departure. To reduce the burden of their journey, Sachiko drowns the kittens in the river. Mariko stands still on the bank, silently following every step of Sachiko's act, in the same way she witnessed that Tokyo woman holding her baby under the water. After Sachiko lets go the box with the kittens in it, Mariko runs crazily along the river with an attempt to rescue them, but to no avail. It is only under the consolation of Etsuko that Mariko agrees to come back to the lonely cottage.

This is the climactic part in Etsuko's memory of the past. The Nagasaki tale is framed within the outer tale of Etsuko several decades later in a country house of England. During her younger daughter Niki's five days'stay, Etsuko is caught in recalling that summer when she befriended Sachiko and Mariko because Niki comes back "out of a sense of mission," that is, to reassure Etsuko that she is not responsible for the recent death of Keiko. A couple of months ago, Keiko, Etsuko's daughter by her first husband Jiro, was found hanging herself in her Manchester apartment. The effect of this trauma takes shape in the nightmares of Etsuko and the eerie atmosphere hovering Keiko's former bedroom. During these five days, neither Etsuko nor Niki can sleep well at night, and both are disturbed by dreams. Etsuko's dream revolves around the small girl they have seen in the park. The girl is playing on the swings. As Etsuko sees it, the appearance of such an image in her dream is a result of her having remembered Sachiko and Mariko these days. The little girl could be the shadow of Mariko. The more she remembers about Mariko, the more clear it becomes that Mariko is the alter-ego of Keiko, as Sachiko is Etsuko's alter-ego. As Sigmund Freud (1966) interprets about dreams:

The conception of dream-elements tells us that they are ungenuine things, substitutes for something else that is unknown to the dreamer (like the purpose of a parapraxis), substitutes for something the knowledge of which is present in the dreamer but which is inaccessible to him....(p.114)

The dream is a substitue for something unconscious, particularly something one manages to evade. Through the dream, what is unconscious surfaces to the conscious.

In Etsuko's case, the images of the swinging girl, Mariko and Keiko overlap in that they are roughly of a similar age and the image of rope ties them together as one. For the girl in the park, the swinging board is held up by the rope; Mariko has been twice startled by the rope which tangles around Etsuko's ankle; Keiko hangs herself with a rope-like stuff. More than that, when Etsuko first meets Mariko, the girl's indifference arouses in her "every kind of misgiving about motherhood," for she is several months pregnant with Keiko. And in that summer, Etsuko, Sachiko and Mariko have the excursions to Inasa, the hilly area of Nagasaki overlooking the harbour. However, in Etsuko's talk to Niki in the outer frame story, she remembers that "Keiko was happy that day. We rode on the cable-cars" $(P V H$, p.182). Another time for the confused identities of Mariko/Keiko, Sachiko/Etsuko occurs after Sachiko's drowning Mariko's kittens. The searching for Mariko brings Etsuko to the bridge since Mariko is convinced that the strange woman lives among the woods on the other side of the river. To comfort Mariko who does not want to go to America, Etsuko promises that "In any case, if you don't like it over there, we [my italics] can always come back...If you don't like it over there, we'll come straight back. But we have to try it and see if we like it there. I'm sure we will”(p.173). Here, Etsuko's use of "we" four times underlines her own identification with Sachiko, Keiko's with Mariko. These words may be what she has said to Keiko when she brought her to England. Like Sachiko who believes that America is the best place for Mariko's education and future, Etsuko does not consider Keiko's feeling about living in a strange land. The cultural dislocation and emotional separation from her father lead Keiko into deeper isolation:

For the two or three years before she finally left us, Keiko had retreated into that bedroom, shutting us out of her life. She rarely came out, although I would sometimes hear her moving around the house after we had all gone to bed...She had no friends, and the rest of us were forbidden entry into her room...In the end, the rest of us grew used to her ways, and when by some impulse Keiko ventured down into our living room, we would all feel a great tension. (pp. 53-4)

Now the memory of Sachiko and Mariko drives home to Etsuko that she is wrong in taking Keiko to England and in severing her tie with Jiro who was a good father to her during the seven years he knew his daughter. The senses of guilt and grief develop so strongly that Etsuko sees the bedroom of Keiko as being haunted by the ghost. Like Sethe in Tony Morrison's Beloved, Etsuko cannot expel the memory of her deceased daughter. Though she does not perform the act of killing as Sethe does, she is to blame for the early death of Keiko. As Anne Whitehead (2004) argues in Trauma Fiction that

if trauma is at all suscptible to narrative formulation, then it requires a literary form which departs from conventional linear sequence. The irruption of one time into another is figured by Caruth as a form of possession or haunting. The ghost represents an appropriate embodiment of the disjunction of temporarilty, the surfacing of the past in the present. (p.6)

The ghost of Keiko lingers in the house. In the early morning, Etsuko feels that "someone had walked past my bed and out of my room, closing the door quietly" ( $P V H, \mathrm{p} .174)$; standing outside Keiko's room, she seems to hear "a small sound, some movement from within" (p.88); Niki also complains about some unusual sounds, and she even asks on the fourth day to move to the spare room since sleeping in the room opposite to Keiko's sets her uneasy. At the level of the individual psyche, the ghost of Keiko reworks the unresolved trauma of the past in Etsuko, not only for the recent death of Keiko but also for the painful experiences decades back in Nagasaki. 
An Artist of the Floating World takes the subplot of A Pale View of Hills. Ogata-San, Etsuko's father-in-law in A Pale View of Hills, pays a visit to Etsuko and Jiro from Fukuoka that summer when she encounters Sachiko and Mariko. Ogata-San who has been a distinguished painter and teacher has another purpose in mind when he stays with them. He intends to have a talk with his former student Shigeo Matsuda because the latter has written an article condemning Ogata and his peers for having misled the young into fighting for militarism. The dissensions between the old generation and the young about traditional Japanese values, the nature of art and Americanization compose the principal issues of An Artist of the Floating World. All these issues are unfolded within the framework of Masuji Ono's efforts to clear away the obstacles in his younger daughter Noriko's marriage negotiations. To his surprise, the greatest obstacle comes from himself, for he has worked for the imperialist government with his propaganda posters. His misdeeds account for the failure of last year's marriage negotiations with the Miyakes, which compels him to reexamine his "glorious" past.

Like Etsuko whose mind is fixated on the Nagasaki tale in the early 1950s, Masuji Ono mainly dwells on his achievements in the 1930s when his artistic work contributed to the rise of militarism. Feelings of nostalgia and melancholia permeate their narratives of the past. In both novels, there is an image of the bulldozer, a kind of powerful tractor that pushes a broad steel blade or sheet in front, used for levelling land and shifting large quantities of earth, etc. On the sites of reconstruction, it is one of the major machines. Ono stands amazed before such a site, watching the bulldozer "churning up the ground." The working bulldozer symbolically represents Etsuko and Ono's efforts to dive into the pool of their past, bringing to surface those unspeakable memories.

Different from A Pale View of Hills, there is no infanticide nor spirits haunting the locale in An Artist of the Floating World. Gothic features are absent here. However, something sinister is to be heard about from time to time, such as the suicides of the president of Jiro Miyake's company, some of whose undertakings were related to the war, and of Mr. Yukio Naguchi, the composer of military songs before and during the war. Both feel guilty for their war-time deeds to the extent that suicide is the only way for them to apologize to the families of those killed in the war. To these two suicides within two years, Ono gives different responses. It is in 1947 when Ono chanced to meet Jiro Miyake outside his office building. At that time, Noriko's marriage negotiations with him were under the way. Ono could not understand why Jiro picked up the topic of suicide, nor could he share Jiro's view that the president's suicide was a "noble gesture." He felt it was a waste of life. It did not strike Ono that there is something shameful and guilty if one's deeds are motivated by national loyalty. Rather, one should be proud of his patriotism. So he did not see any connection between his war-time work and the Miyakes' withdrawal from marriage negotiations.

If without his older daughter Setsuko's warning that they should take "precautionary steps" during the negotiations with the Saitos to avoid any misunderstandings about the past, Ono would not have thought so much about his career first as a commercial painter, then as a pure artist, and at last as a political painter, nor would he have been able to realize that in the eyes of the young generation he is a coward who does not dare to admit his mistakes. Through his recollections and his reviews about the changed climate, Ono goes through a painful process from self-justification to self-denial. Because of his public confession of his misdeeds before the Saitos at the miai (the formal meeting of the prospective bride and bridegroom's families), Noriko secures the chance of marriage with Taro Saito. As a result, in a later talk with his grandson Ichiro about the suicide of Mr. Naguchi in 1949, Ono expresses a totally different opinion:

But you see, Ichiro, when the war ended, things were very different. The songs Mr Naguchi composed had become very famous, not just in this city, but all over Japan. They were sung on the radio and in bars. And the likes of your Uncle Kenji sang them when they were marching or before a battle. And after the war, Mr Naguchi thought his songs had been - well - a sort of mistake. He thought of all the people who had been killed, all the little boys your age, Ichiro, who no longer had parents, he thought of all these things and he thought perhaps his songs were a mistake. And he felt he should apologize. To everyone who was left. To little boys who no longer had parents. And to parents who had lost little boys like you. To all these people, he wanted to say sorry. I think that's why he killed himself. Mr Naguchi wasn't a bad man at all, Ichiro. He was brave to admit the mistakes he'd made. He was very brave and honourable. ( $A F W$, p.155)

Though Ono does not approve of suicide as a way of redemption, he begins to appreciate their courage of acknowledging their responsibility for the deaths of so many young men.

\section{THE DECLINE OF BRITISH EMPIRE}

Beginning with Henry VII in the late $15^{\text {th }}$ century, Britain never ceased its attempt to expand its overseas territory in the following four to five centuries. At one time, it ruled approximately one-fourth of the world's population, thus acquiring the name as the empire on which the sun never sets. However, due to the widespread liberalism in the wake of the Second World War, there arose the moves toward self-government in former British colonies in Asia, Africa and the Americas. India, Pakistan, Burma, Ceylon respectively achieved their independence in the late 1940s. If Britain was to maintain its imperial presence, British government in the 1950s had to adjust its colonial policy to meet the "demands for constitutional advance, or even self-governement, from nationalists"(Lynn, 2006, p.2). Some in the government, like the Secretary of State for the Colonies, Oliver Lyttelton (1951-54), and his successor, Alan Lennox-Boyd (1954-59) saw the urgency of pragmatic cooperation with outcries for self-government in some areas. Yet the pervailing voice from the Conservative government under Winston Churchill (1951-55) and Anthony Eden (1955-57) was to resist the hasty 
'retreat' from overseas territories. They felt it something decades away or even a century away. It is made clear that during the premierships of Churchill and his successor Eden, "no territory received its independence from Britain with the exceptions of Libya and Sudan, both of which had an unusual status"(p.4). So the Conservative imperial policy was featured by "concessions where essential, military resistance to nationalism where necessary, support for settlers where possible" (p.5). Despite the conservatives' ambition to revitalize its imperial power across the globe and to maintain its independence of the United States, the Suez crisis in 1956 plunged Britain into a political catastrophe when the United States opposed British, French and Israeli intervention in Egypt and refused to "support sterling on the world money markets" (p.8). What followed the Suez crisis was the declining influence of Britain in the Middle East, east of Suez or Africa. Under these circumstances, the newly elected Prime Minister Harold Macmillan (1957-63), reevaluated British policy and recognized the importance of developing a closer tie with the United States, especially in the issues of defence system and economy. At the same time, Macmillan proposed a 'cost-benefit analysis' of the value of colonies, in which he suggested that "Britain could safely withdraw from much of the empire with little economic loss to herself" (p.9). Then with Macleod taking charge of the Colonial Office in 1959, who favored the moves towards decolonisation, along with the exposure of "the Hola camp atrocities in Kenya in 1959 when 11 camp inmates were beaten to death by their guards" (p.10), the pace of decolonisation picked up its speed:

The Gold Coast (as Ghana) had gained its independence in 1957, while Nigeria, Britain's largest colonial territory aftrer 1947, was to gain its independence in 1960. In the case of Kenya, the Lancaster House conference in 1960 saw significant moves towards majority rule and ultimate independence. Simultaneously moves were being made towards independence in Tanganyika and Uganda; the three East African territoris were to get their indepence in 1963, 1961 and 1962 respectively. In Central Africa, the outcome of the 1959 emergency led to the London conference of 1960 and the break-up of the Federation in 1963; Nyasaland (as Malawi) and Northern Rhodeisa (as Zambia) gained their independence the following year. Elsewerhe, the collpase of the Federation of the West Indies led to independence for Jamaica in 1962 followed by Trinidad and Tobago in the same year and Barbados in 1966. (p.10)

Thus the British empire with the sun never setting has to come to terms with the fact of its collapse and its status as the superpower being replaced by the United States of America. Ishiguro's third novel, The Remains of the Day is set in July, 1956. Coincidentally, it is in July of 1956 "when Egyptian President Gamal Abdul Nasser nationalized the Suez Canal, precipitating Britain's military fiasco and signifying the end of its colonial influence" (Lee, 1989, p.762). Related to this historical setting is the cultural landscape of Britain in the 1980s, during which Margaret Thatcher's conservative government aimed to emulate the Victorians. Thatcher in a speech for the election campaign expressed the wish to reglorify Great Britain.

Stevens, the butler of Darlington Hall in The Remains of the Day, entertains such a sense of British greatness. Not only does the English landscape at its finest possesse "a quality that the landscapes of other nations, however more superficially dramatic, inevitably fail to possess... and this quality is probably best summed up by the term 'greatness'...We call this land of ours Great Britain"' $(R D, \mathrm{p} .28)$, but also real butlers can only be found in England: "Other countries, whatever title is actually used, have only manservants... Continentals are unable to be butlers because they are as a breed incapable of the emotional restraint which only the English race are capable of" (p.43).

These provide the backgrounds against which Stevens reminisces about his professional life in the 1920s and 1930s when Darlington Hall was in its heyday, hosting quite a few "unofficial" conferences. With the death of Lord Darlington three years ago, the Darlington family who has owned the house for two centuries sold it out to an American businessman, Mr. Farraday, a transaction symbolic of the change of power relation between Britain and the United States. In its best time, also the best time of Steven's profession, the house has hired a staff of seventeen, on some particular occasions a staff of twenty-eight. But now, Stevens has only a "skeleton team" of four resident employees, which forces him to design a very tight working schedule for each of them. The lack of working hands unavoidably results in some errors, which gives Stevens much anxiety since he values the perfect performance of duites so much that he cannot forgive himself for any error. It is just at the time when he considers recruiting a new staff that he receives the letter from Miss Kenton, the former housekeeper who went to Little Compton, Cornwall after her marriage 20 years ago. As Stevens judges, there is in the letter "an unmistakable nostalgia for Darlington Hall, and - I am quite sure of this distinct hints of her desire to return here" ( $R D$, p.9). Therefore at the proposal of Mr. Farraday that he should drive off somewhere instead of being "locked up here in this house," Stevens starts his first long trip in Mr. Farraday's Ford after 35 years'service at Darlington Hall, and he plans a five or six days' motorcade to the West Country with Cornwall as his destination.

"The expedition" to the west turns out to be a metaphorical journey of introspective self-exploration. Once he drives out of the familiar neighbourghood, he has a slight sense of "alarm": "a sense aggravated by the feeling that I was perhaps not on the correct road at all, but speeding off in totally the wrong direction into a wilderness" (p.24). The surroundings growing unrecognizable, Stevens has treked into a totally uncharted area "beyond all previous boundaries." In his case, for the first time he begins to reevaluate his service to Lord Darlington who was harshly criticized as a Nazi sympathizer after World War II.

Stevens has been so proud of working for Lord Darlington because he can vicariously contribute to the development of human civilization through his dutiful service to a distinguished household. Darlington Hall is one of "great houses" within whose walls some crucial decisions affecting the nation or even the world will be arrived at and then be simply 
concluded with certain pomp and ceremony in the public chambers. So when Lord Darlington gathered those important figures in his house for those crucial matters in 1923 and 1936, it never occured to Stevens that these meetings were partly responsible for the rise of German Nazism, for Lord Darlington out of his modest and benevolent nature merely intended to alleviate Germany from the harsh penal terms of the Versailles Treaty and to build a closer tie with German government. What occupied Stevens's mind was that these were trying moments testing whether he could demonstrate the expected quality a great butler should possess, that is 'dignity.'

The occurrences prove that Stevens deserves the title of a great butler. In the first occasion of 1923, he was faced with a dilemma between the smooth management of household affairs and the fall of his father Old Stevens. The call of duty as a dignified butler demanded him to suppress his sorrow at the news of his father's death during the banqueting time, for he knew that this was what would be expected from his father who had been a model of bulter for Stevens to follow. In the second occasion of 1936, Lord Darlington had several distinguished guests for private meetings. Stevens was again pushed by so many duites, yet at the same time he had to control his emotion after Miss Kenton told him that she had agreed to marry her former acquaintance. It is obvious that mutual respect and affection secretly developed in the bosoms of Stevens and Miss Kenton, but Stevens's inclination to disguise his true feelings disappointed Miss Kenton so much so that she decided to marry the man she did not love. These two occasions best exemplify the principle Stevens has held onto: To become a great butler, he has to sacrifice his private life. Stevens's professional commitment deprives him of the most crucial part of human life, that is human companionship.

As arranged, Stevens has a meeting with Miss Kenton on the fourth day, and it turns out to be only a two hours' hasty talk. Miss Kenton admits that in her depression she has thought about a life she may have had with Stevens, but with years wearing away she has grown to love her husband, and they are now anticipating the birth of their first grandchild. The pity of not being able to have Miss Kenton back to the Darlington Hall brings Stevens to the seaside town of Weymouth to see the lighted pier at dusk so that he can allow himself a whole day to spend in "a leisurely manner." There, while waiting for the coloured lights to switch on, he strikes up a conversation with a stranger who happens to be a retired butler. For the first time during this trip, he acknowledges his relation with Lord Darlington and confesses that he has been a coward in not daring to admit his mistakes. Before that, he has denied his knowledge of Lord Darlington three times in the way Simon the Peter denied his tie with Jesus Christ and has transferred his share of responsibility onto Lord Darlington by claiming that "a butler's duty is to provide good service. It is not to meddle in the great affairs of the nation"(p.199). This confession successfully removes the burden of guilt from his mind, and he is ready to confront what remains of his life as suggested by the stranger that "the evening's the best part of the day. You've done your day's work. Now you can put your feet up and enjoy it” (p.244).

Like Ogata-San in A Pale View of Hills and Ono in An Artist of the Floating World, Stevens wrestles with his reassessment of identity, realizing that he has wasted his life as a result of his loyal service to Lord Darlington's appeasement with German nationalism. These three men, together with Etsuko, have all undergone a painful process of self-examination from self-deception to self-denial and finally to self-redemption through their confession of the past mistakes, either private or public. Therefore toward the end of each book, they can all reach a new understanding of life and values and reconstruct their identities.

\section{Opium Trade in China And Shanghai Battle}

After finishing the first two novels, Ishiguro suffered from critical tendency to stereotype him as a Japanese author. To escape from such a label, Ishiguro portrayed an English butler in The Remains of the Day. Its journey motif, exploration of English gentry culture and its employment of English literary traditions all speak to the critics and reviewers that he could express the Englishness as delicately as an English writer if not better. By his fourth novel, The Unconsoled, Ishiguro proves that he is a complex person behind his Japanese screen because it follows Kafka's style of surrealism in relating Ryder's mysterious experiences in a geographically unspecified European city. Then in When We Were Orphans, he mingles the two cultures he is most familiar with, with each culture culpable for certain part of Chinese traumatized history: British for the opium trade and Japanese for the Asia-Pacific War.

Chinese people first knew opium as a kind of medical substance in the eighth century. It is until the seventeenth century that opium became an object of recreational consumption when Dutch and English traders expanded their business networks into China. The moral, social and political implications of opium addiction were not the concerns of British traders who were only interested in its great commercial profits. It is not an exaggeration to say that opium trade supported the survival of the British empire in the $19^{\text {th }}$ century. As Timothy Brook and Bob Tadashi Wakabayashi (2000) note:

By 1854, when China became third after the United States and France among suppliers of imports to an overextended Great Britain, the value of goods (principally tea and silk) from China totaled more than nine times the value of British exports to China. The gap could be filled only by Indian opium, and in ever-increasing amounts. Without it, Britain could not hope to reverse its dreadfully skewed balance of payments with China into the black - short of asking the British to give up drinking tea (or to grow tea in India, which they eventually did do). (p.7)

Despite the efforts of Chinese government to ban the sale and distribution of opium, including Emperor Yongzheng's edict of 1729 identifying "the smokers as legally culpable" and the activist official Lin Zexu's heroic act of destroying about twenty thousand chests of opium in 1838, opium trade was on the rise due to the growing domestic demand, 
especially after the two opium wars (1839-42, 1856-60), the result of which faciliated the trade with some coastal cities becoming concessions. While great amounts of silver flowed to British traders, Chinese people suffered from abuse of opium: damaged health and mind, disintegrated family, and demoralized social structure, etc. In When We Were Orphans, the Chinese inspector Mr. Kung falls to be the victim of opium.

Christopher Banks, now a famous English detective, comes back to Shanghai in 1937 to investigate the case of his parents' disappeareance almost 30 years ago when he was around 9. Inspector Kung who has been responsible for that case may have some information about a house where Banks feels convinced that his parents are still held captives. When he pays a visit to him, Banks is shocked to see that the once heroically mysterious figure has been greatly disfigured by opium:

Former inspector Kung looked to be little more than bones. The skin on his face and neck was shrivelled and spotted; his mouth hung open slackly; a bare, stick-like leg was protruding rom the coarse balnket, though on his top half I saw he had on a surprisingly white undershirt. ( $W W W O$, p.203)

His mind is muddled, and sometimes he cannot even remember the thing of the day before. To recollect the memory about that unresearched house years ago, he has to rely on opium. Inspector Kung does not disappoint Banks, telling him the next day on the phone that the house is opposite to that of a blind man named Yeh Chen.

The disappearnce of Banks's parents is related to the opium trade. In the early 1900s, Banks's father worked for Morganbrook and Byatt company which imported opium from India to China. Mrs. Banks, after discovering the nature of the company's business, joined the anti-opium campaign. One day, the health inspector from the company came to their house for the regular check of the house hygiene. He demanded Mrs. Banks to dismiss their maid Mei Li only because she was from Shantung:

Opium addiction in Shantung has now advanced to such deplorable levels that entire villages are to be found enslaved to the pipe. Hence, Mrs Banks, the low standards of hygiene, the high incidence of contagion. And inevitalby, those who come from Shantung to work in Shanghai, even if essentially of an honest disposition, tend sooner or later to resort to thieving, for the sake of their parents, brothers, cousins, uncles, what you have, all of whose cravings must shomehow be pacified. (p.59)

At his remarks, Mrs. Banks lost her temper, pointing out to him the evil trade they were doing. "Are you not ashamed, sir? As a Christian, as an Englishman, as a man with scruples?... Tell me, how is your conscience able to rest while you owe your existence to such ungoldly wealth?" (p.60) To stop the opium trade, Mrs Banks tried to convert the people whom she knew kept some relationship with the company. She would be most eager to see the transformation in her husband who was hesitant about acting against the company's benefit. One morning Mr. Banks left the house as usual, but he did not return in the evening. In Banks's mind, his father must have been kidnapped for the anti-opium campaign because his mother comforted him by saying that he should be proud of what father had done. After this incident, young Banks and his Japanese friend Akria always played their detective games, designing their scenarios of searching for and rescuing father.

Due to mother's care and Uncle Philip's encouragement, whom Banks adored as a substitue father, the impact of father's disappearance on Banks was not so serious except his engrossment in the detective games. Yet, the following disappearance of mother traumatized Banks to the extent that he changed from a sunny boy to a silent and melancholy one. Being orphaned, he was sent back to England under the care of his aunt. Although Banks had done his greatest efforts to integrate himself into the new life, modelling his manners after his schoolmates, he secretly indulged himself on the ideas of crime and its detection. He enacted the detective scenarios over and over during those drizzly days, filling his empty hours wandering about the ferns near his aunt's cottage. As Freuds interprets about the connection between the hypnoid 'dream-like state of consciousness' and sexual traumas in chilhood: "It is exaclty this dream-like state, dominated by primary process in which phantasy and reality can no longer be reliably differentiated, that occurs when mental life re-appears after traumatic events" (qtd. in Zepf, 2008, NP). Trauma may revisit the victim in different forms. To Banks, his constant replaying of the scenarios suggests the futility of forgetting the past.

The obsession with his parent's disappearance motivates Banks to become a Holmes-like detective. After graduation from Oxford in 1923, he has established his fame for several intricate cases. In the meantime, he never gives up collecting data concerning his parents' disappearance. Once he forms some clear idea about it, he makes the decision to go back to Shanghai. Another factor propelling him to go there is the crisis in China. As a detective, Banks entertains the idea that he is entrusted with a mission to combat the evil. His self-imposed sense of duty is consolidated by his friends who think that he knows better than most people about the impending war and that they need to rely more than ever the likes of his who can "spot their game quickly, destroy the fungus before it takes hold and spreads" ( $W W W O$, p.44). Driven by his determination to eradicate the ills from the earth and his eagerness to solve out the riddle of his parents' disappearance, Banks arrived at Shanghai in September, 1937 when Japanese troops were launching attacks on the city.

After the invasion of Manchuria in 1931, Japan gradually pushed its occupied territory from Northeast China to Beijing in 1937. The Marco Polo Bridge Incident on July $7^{\text {th }}$ marked the beginning of the full-scale war between China and Japan. A month later, on August 13, 1937 "Japanese marines crossed the Shanghai-Wusong Railway to attack Chinese troops stationed on the Bazi Bridge and Baoshan Road. The fighting quickly spread to Jiangwan, Pudong, Yangshupu, and Hongkou - 'Little Tokyo"' (Fu, 1993, p.2). The Battle of Shanghai lasted about 3 months into 
November 12 with the retreat of Chinese troops from the defense line. Though it was a failure on Chinese part, the Battle of Shanghai destroyed the Japanese ambition to conquer entire China within 3 months.

With the battle under the way, most parts of the city turned into a slaughterhouse. According to the North-China Daily News reporter Rhodes Farmer's description of the post-bombing scenes:

Yellow, slowly lifting, high explosive fumes exposed a terror scene in [Nanjing] Road. Flames from blazing cars were incinerating the bodies of their riddled occupants. In grotesque heaps where they had been hudding in doordays and annexes of the Cathay and Palace hotels were heaps of refugees whose blue coolie clothes were turning red. Heads, arms, legs lay from mangled trunks. For the full long stretch of both bulilings, pavements and roadway were littered with bodies. (qtd. in $\mathrm{Fu}, 1993$, p.3)

Such a horrendous sight also appears before Banks on his way to the uninvestigated house with the help of a Japanese soldier whom he recognizes as his childhood playmate Akira:

The damage was so extensive, we would frequently have to halt, unable to find a way through the debris. And while it was undeniably a help to see where we were setting down our feet, all the ghastliness that had been hidden by the darkness was now visible to us, taking a profound toll on our spirits. Amidst the wreckage, we could see blood sometimes fresh, sometimes weeks old - on the ground, on the walls, splashed across broken furniture. Worse still - and our noses would warn us of their presence long before our eyes - we would come across, with disconcerting regularity, piles of human intestines in various stages of decay. ( $W W W O$, p.264)

When they finally come to that house, what Banks finds there is only a girl and her dog alive with three corpses lying in the debris. Of course, there is not any trace of his parents. Banks's insistence of investigating this house is simply an enactment of his long-cherished wish. His entry into the ruined house signifies his direct confrontation with the reality. Two days later, the arranged meeting with the Yellow Snake shatters all his old fantasies about the past.

For years Banks has been following the track of the Yellow Snake because he believes that he might get involved in his parents' disappearnce. To his surprise, the Yellow Snake turns out to be Uncle Philip who plays the role of a double informer for both the communists and Kuomintang. As Uncle Philip unravels the mysteires, it dawns on Banks that compared with his trauma of orphanage, his mother's case is more heart-rending and that he has been living in a self-created world about his childhood. Father was not kidnapped, but eloped with his lover when mother's expectation of his work ethics became a pressure to him. It is only for the sake of Banks's growth that mother and Uncle Philip kept it a secret from him. After father's disappearance, mother was forced to marry Wang Ku, that Chinese warlord with whom Uncle Philip had cooperated in stopping the company's opium trade, but the opium shipments would be seized by Wang Ku. Seeing it impossible to persuade Wang Ku into giving up his lust for Mrs. Banks, Uncle Philip agreed to help him abduct her provided that young Banks should not be taken away. Seven years later, Uncle Philip got the chance to travel through Hunan and meet her, learning that if not for her son, she would have taken her life without a moment's hesitation. Mother complied with Wang Ku, tolerating his tortures like being regularly whipped in front of his dinner guests. In return, Wang Ku would financially support Banks's life and schooling. At this stage, Banks realizes that all these years he has been living on the money of Wangku instead of his aunt's heritage. In this sense, Banks's well-provided life on the basis of a Chinese opium-dealer's support parallels that of English people whose material comfort to a great extent derives from the opium trade with China.

Years' enslavement, humiliation and concubinage afflict mother's mind so much that she cannot recognize Banks at all when he finally goes to see her in a Hong Kong nursing home after the war. Even Banks's act of holding her hands sets her uneasy. What she can remember is only the fact that her son is said to have come off well. So as not to disturb her peace in the last years of her life, Banks decides not to take her back to England. It might be better for her to stay in the East where she has lived her whole life.

With When We Were Orphans, Kazuo Ishiguro for the first time gives some direct treatment of the bloody war scenes which might arouse feelings of sickness and sadness in the reader. In the first two novels, Nagasaki simply provides the backdrop against which Ishiguro explores the mental track of the protagonists. There are no bombing scenes except several paragraphs describing the reconstruction work and the unnoticed ruins. The reader might unconsciously dwell on the personal arena only while ignoring its historical implications. Those appalling parts concerning death and killing in When We Were Orphans can be more effective in calling young readers' attention to the catastrophe a war will incur to the people and the society, thus enhancing readers' historical consciousness.

\section{CONCLUSION}

In Ishiguro's fiction, history recedes into the background, and individual struggle against the odds of life is highlighted in the foreground. Ishigurian protagonists are distinguished by their dignity, responsibility, and courage to reconcile with the perversities of life. His fiction usually ends with a hopeful note, suggesting that the protagonists will be able to move forward while burying the bleak past deep in their minds.

\section{ACKNOWLEDGEMENTS}

The author is greatly indebted to the supervision of Professor Yaoxin Chang who has offered many valuable advices on the completion of this paper and given careful corrections to its language and structure. 


\section{REFERENCES}

[1] Brook, Timothy and Bob Tadashi Wakabayshi. Eds (2000). Opium Regimes: China, Britain, and Japan, 1839-1952. Berkeley, CA: University of California.

[2] Caruth, Cathy (1995). "Trauma and Experience: Introduction.” Trauma: Explorations in Memory. Ed. Cathy Caruth. Baltimore: Johns Hopkins UP. 3-12.

[3] Freud, Sigmund (1966). Introductory Lectures on Psychoanalysis. New York: W.W. Norton.

[4] Fu, Poshek (1993). Passivity, Resistance, and Collaboration: Intellectual Choices in Occupied Shanghai, 1937-45. Stanford, California: Stanford UP.

[5] Gallix, François. (2008). "Kazuo Ishiguro: The Sorbornne Lecture.” Conversations with Kazuo Ishiguro. Eds. Brian W.Shaffer and Cynthia F. Wong. Jackson: UP of Mississippi. 135-55.

[6] Ishiguro, Kazuo (1988). A Pale View of Hills. London: Faber and Faber.

[7] ---(1988). An Artist of the Floating World. London: Faber and Faber.

[8] --- (1990). The Remains of the Day. New York: Vintage International.

[9] --- (2000). When We Were Orphans. London: Faber and Faber.

[10] Ishikawa, Eisei (1981). Hiroshima and Nagasaki: The Physical, Medical, and Social Effects of the Atmoic Bombings. Trans. David L. New York: Swain. Basic Books.

[11] Lee, Sanne Wah. (1989). “Of Dignity and Servility.” The Nation. December 18. 761-63.

[12] Lynn, Martin. Ed. (2006). The British Empire in the 1950s Retreat or Revival? Houndmills, Hampshire: Palgrave Macmillan.

[13] Whitehead, Anne (2004). Trauma Fiction. Edinburgh: Edinburgh U.P.

[14] Zeph, Siegfried and Florian D. Zepf. (2008). "Frued's Concepts Revisited." International Journal of Psycholanalsis. 89: 331-353.

Deyan Guo is a Ph. D. candidate of English literature at College of Foreign Languages, Nankai University. Currently she also holds a teaching post as Associate Professor at Tianjin Foreign Studies University. Her academic interests cover contemporary British and American literature. This paper is a part of the project titled "Historical Narratives in Ishiguro, Phillips and Okri." The project no. is TJWW11-013. 